\title{
Detection of Epstein-Barr virus DNA in nasopharyngeal carcinoma using a non-radioactive digoxigenin-labelled probe
}

\author{
A.M.Y. Permeen ${ }^{1}$, C.K. Sam ${ }^{1}$, R. Pathmanathan ${ }^{1}$, U. Prasad ${ }^{1}$ and H. \\ Wolf ${ }^{2}$ \\ ${ }^{1}$ Nasopharyngeal Carcinoma Research Laboratory, Institute of Advanced Studies, University of \\ Malaya, Kuala Lumpur, West Malaysia and ${ }^{2}$ Max von Pettenkofer Institute, F.R.G.
}

(Accepted 10 November 1989)

\section{Summary}

The presence of Epstein Barr virus (EBV) DNA in biopsies from the post-nasal space (PNS) of patients suspected of nasopharyngeal carcinoma (NPC) was detected by in situ cytohybridisation with an EBV DNA probe labelled with the novel labelling compound digoxigenin. The digoxigenin probe was hybridised to cryostat sections of NPC biopsies and subsequently detected by an enzyme immunoassay procedure. It was found that in situ cytohybridisation using the digoxigenin probe was much more rapid and sensitive ( $96 \mathrm{~h}$ compared to five weeks) than the current method of using ${ }^{3} \mathrm{H}$-labelled probe. Using the digoxigenin EBV probe, it was found that in all the eighteen NPC biopsies tested, EBV DNA was detected in malignant epithelial cells and infiltrating lymphocytes. EBV DNA was also detected in some normal epithelial cells in these NPC biopsies. EBV DNA was not detected in epithelial cells of non-malignant biopsies.

Digoxigenin; Epstein-Barr virus; Nasopharyngeal carcinoma

\section{Introduction}

Nasopharyngeal carcinoma (NPC) is closely associated with the Epstein-Barr virus (EBV). The association was first realised when the majority of NPC patients

Correspondence to: C.K. Sam, Nasopharyngeal Carcinoma Research Laboratory, Institute of Advanced Studies, University of Malaya, 59100 Kuala Lumpur, West Malaysia. 
were found to have elevated antibodies to EBV antigens (Old et al., 1966; Henle et al., 1970). Direct evidence of the presence of EBV in NPC was demonstrated by the presence of DNA in the malignant epithelial cells with the use of radioactive EBV probe (zur Hausen et al., 1970; Nonoyama et al., 1973; Wolf et al., 1973; Klein et al., 1974). Recently, there has been much interest in developing non-radioactive labels for probes, since the use of radioactivity carries inherent dangers and inconvenience. A non-radioactive, digoxigenin probe was used successfully for the detection of DNA binding factors using protein-blotting technique (Dooley et al., 1988). We report a study using digoxigenin-labelled EBV DNA in in situ cytohybridisation of NPC biopsies.

Digoxigenin is a hapten steroid, classed under the Cardenolides $\left(\mathrm{C}_{23}\right)$ group. The deoxyuridinetriphosphate (dUTP) molecule is linked via a space-arm to the digoxigenin at the $\mathrm{C}_{3}$ position using the random primed DNA labelling method (Feinberg and Vogelstein, 1983). The digoxigenin is labelled to all the BamHI fragments of EBV (Skare and Strominger, 1980) except the O and K fragments due to crossreactions with cellular DNA. The ${ }^{3} \mathrm{H}$-labelled EBV probe used in this study was labelled only to the $\mathrm{W}$ fragments of EBV.

\section{Materials and Methods}

\section{Biopsies}

Tissue biopsies from 24 patients with clinical symptoms of NPC from University Hospital Kuala Lumpur were used for this study. Biopsies were taken from the post-nasal space (PNS), snap frozen and stored in liquid nitrogen until use. Snap frozen tonsil specimens were used as the negative tissue controls.

\section{Sections}

Sections used in the in situ cytohybridisation were cryostat sections cut at $5 \mu \mathrm{m}$ thickness using a Reichert Histostat Cryostatmicrotome knife $(185 \mathrm{~mm})$.

\section{DNA probes}

Probes used in this study were the ${ }^{3} \mathrm{H}$-labelled EBV DNA (specific activity: 1.5 $\left.\times 10^{7} \mathrm{cpm} / \mu \mathrm{g}\right)$ and the digoxigenin labelled EBV DNA $(20 \mathrm{ng} / \mu \mathrm{l})$.

\section{Cell lines}

The EBV positive lymphoblastoid lines P3HR-1, Raji and B95-8 were used as positive cell controls and EBV negative lymphoblastoid line $B J A B$ was used as the negative cell control. 


\section{Chemicals}

All chemical used were of Analar grade or of the highest grade available commercially. Buffers and all solutions used were steam sterilized at $121^{\circ} \mathrm{C}(15 \mathrm{psi})$ for $20 \mathrm{~min}$. Solutions which were heat labile were sterilized by filtration through sterile membrane filters $(0.22 \mu \mathrm{m}$ pore size $)$.

\section{Pretreatment of slides and coverslips}

Slides used in the in situ cytohybridisation technique had to be made certain of their cleanliness and their adhesive surface for tissue sections to adhere securely. 1. Slides were soaked in ethanol:acetone $(1: 1 \mathrm{v} / \mathrm{v})$ overnight. 2 . The following day the slides were baked at $100^{\circ} \mathrm{C}$ for $1 \mathrm{~h}$. 3 . Incubation in a mixture of $3 \times \operatorname{SSC}(0.45$ $\mathrm{M} \mathrm{NaCl}, 0.045 \mathrm{M}$ tri-sodium citrate dihydrate buffer), $0.02 \%$ Ficoll, $0.02 \%$ polyvinyl pyrrolidone (PVP), $0.02 \%$ bovine serum albumin (BSA) for $3 \mathrm{~h}$ at $65^{\circ} \mathrm{C}$. 4. Slides were dipped briefly in bidistilled water. 5. Fixation with ethanol:acetic acid $(3: 1 \mathrm{v} / \mathrm{v})$ for $20 \mathrm{~min}$. 6. Slides were air dried and stored at $-70^{\circ} \mathrm{C}$. 7 . The coverslips were dipped in siliconizing solution, air dried and baked at $100^{\circ} \mathrm{C}$ for 2 h. 8. Coverslips were stored at room temperature (RT). 9. Tissue sections and cell suspensions were placed on the pretreated slides, air dried, wrapped with aluminium foil and stored at $-70^{\circ} \mathrm{C}$.

In situ cytohybridisation using the digoxigenin-labelled probe was as follows:

Slides with sections or cells are brought to RT and unwrapped followed by: 1 . Fixing in $4 \%$ paraformaldehyde for $2 \frac{1}{2}$ min. 2. Washing twice in PBS/5 mM MgCl for $10 \mathrm{~min}$ at RT. 3. Washing once in $2 \times \mathrm{SSC} / 5 \mathrm{mM}$ EDTA for $30 \mathrm{~min}$ at $50^{\circ} \mathrm{C}$. 4. Incubation with $1 \mu \mathrm{g} / \mathrm{ml}$ proteinase $\mathrm{K}$ in PBS for $15 \mathrm{~min}$ at $37^{\circ} \mathrm{C} .5$. Washing in PBS $/ 0.2 \%$ glycine for 10 min at RT. 6 . Post-fixation with $4 \%$ paraformaldehyde for 10-30 min at RT. 7. Washing twice in PBS/5 mM MgCl 2 for $10 \mathrm{~min}$. 8. Incubation with $50 \mu$ l of prehybridisation mixture $(6 \times \mathrm{SSC}, 45 \%$ formamide, $5 \times$ Denhardt solution and $100 \mu \mathrm{g} / \mathrm{ml}$ heat denatured salmon testes DNA) for $15 \mathrm{~min}$ at RT. 9. The prehybridisation mixture was removed and $20 \mu \mathrm{l}$ of the hybridisation solution was added on each slide, which consisted of $6 \times$ SSC, $45 \%$ formamide, $5 \times$ Denhardt solution, $10 \%$ Dextran sulphate and $20 \mathrm{ng} / \mathrm{slide}$ of the digoxigenin labelled EBV DNA probe. 10. Siliconized coverslips were placed on the slides and sealed with rubber sealant. 11. Slides were placed on a heating block $\left(95^{\circ} \mathrm{C}\right)$ for 3-5 min. 12 . Immediately the slides were chilled on ice. 13 . Slides were placed in a moist chamber and placed on a waterbath of $42^{\circ} \mathrm{C}$ for $24 \mathrm{~h}$.

\section{Immunological detection}

The detection was performed according to the Boehringer method 'DNA labelling and detection kit, nonradioactive' with modifications.

After $24 \mathrm{~h}$ the coverslips were removed and: 1 . Washed twice for $10 \mathrm{~min}$ in $6 \times$ SSC, $45 \%$ formamide at $42^{\circ} \mathrm{C}$. 2. Washed twice for $5 \mathrm{~min}$ in $2 \times$ SSC at RT. 3 . Washed twice for $10 \mathrm{~min}$ in $0.2 \times \mathrm{SSC}$ at RT. 4. Washed in $100 \mathrm{mM}$ Tris-HCl; 150 
$\mathrm{mM} \mathrm{NaCl}$; pH 7.5 (buffer 1) for $1 \mathrm{~min}$ at RT. 5. Slides were incubated with the blocking reagent $0.5 \%(\mathrm{w} / \mathrm{v})$ in buffer 1 for $30 \mathrm{~min}$ at RT. 6. Briefly washed in buffer 1. 7. Antibody-conjugate (vial 8) was diluted to $150 \mathrm{mU} / \mathrm{ml} \mathrm{(1:5000)}$ in buffer 1. 8. Slides were incubated with $20 \mathrm{ml}$ of the diluted antibody-conjugated solution for $30 \mathrm{~min}$ at RT. 9. Slides were washed twice for $15 \mathrm{~min}$ in buffer 1. 10. Slides were equilibrated for $2 \mathrm{~min}$ with $100 \mathrm{mM}$ Tris- $\mathrm{HCl} ; 100 \mathrm{mM} \mathrm{NaCl} ; 50 \mathrm{mM} \mathrm{MgCl}$, pH 9.5 (buffer 3 ). 11. Colour solution was freshly prepared: $45 \mu$ l nitroblue tetrazolium salt (NBT) solution (vial 9) and $35 \mu$ l X-phosphate solution (vial 10) were added to $10 \mathrm{ml}$ of buffer 3 . 12. Slides were incubated with the colour solution in a narrow plastic container in order to save the solution. The container was sealed and placed in a dark plastic box and left in a dark corner. 13. The colour precipitate started to form within a few minutes and the reaction was completed after one day. 14. The reaction was stopped by washing the slides for 5 min with buffer

TABLE 1

Presence of EBV nucleic acids in NPC biopsies

\begin{tabular}{llcc}
\hline Cases & Histopathology & \multicolumn{2}{c}{ EBV genomic status as determined by } \\
\cline { 2 - 4 } & & Digoxigenin probe & ${ }^{3}$ H probe \\
\hline P 1 & WHO I NPC & ++ & + \\
P 2 & WHO II NPC & + & - \\
P 4 & WHO II NPC & +++ & Not done \\
P 10 & WHO II NPC & + & Not done \\
P 14 & WHO II NPC & + & Not done \\
P 21 & WHO II NPC & + & - \\
P 9 & WHO II \& III (mix) & ++ & + \\
P 13 & WHO II \& III (mix) & ++ & Not done \\
P 3 & WHO III NPC & ++ & - \\
P 5 & WHO III NPC & ++ & - \\
P 6 & WHO III NPC & + & - \\
P 8 & WHO III NPC & ++ & Not done \\
P 11 & WHO III NPC & ++ & Not done \\
P 12 & WHO III NPC & + & - \\
P 19 & WHO III NPC & Not done & - \\
P 20 & WHO III NPC & + & ++ \\
P 24 & WHO III NPC & ++ & + \\
P 25 & WHO III NPC & ++ & - \\
P 7 & Non-malignant & - & - \\
P 15 & Non-malignant & - & + \\
P 16 & Non-malignant & - & - \\
P 17 & Non-malignant & - & - \\
P 22 & Non-malignant & - & - \\
P 23 & Non-malignant & - & - \\
P 18 & Tonsil & - & - \\
P3HR1-K & EBV + ve line & +++ & + \\
B95-8 & EBV +ve line & ++ & - \\
Raji & EBV +ve line & ++ & - \\
BJAB & EBV -ve line & - & + \\
\hline
\end{tabular}

- , Negative; + , slightly positive; ++ , moderately positive; +++ , strongly positive. 
4 (10 mM Tris-HCl; $1 \mathrm{mM}$ EDTA, pH 8.0). 15. Slides were finally counter stained with aqueous eosin solution and mounted with aqueous mount.

\section{Results}

Table 1 shows the results of in situ cytohybridisation using EBV probes labelled with either digoxigenin or ${ }^{3} \mathrm{H}$ on sections of 24 biopsies from the post-nasal space of patients suspected of NPC. Of the 24 biopsies, 17 were read as NPC on parallel sections stained with haematoxylin and eosin.

Using digoxigenin EBV probe, in all 17 cases of NPC, including the one case of WHO I NPC, EBV positive malignant epithelial cells were detected (Fig. 1). EBV DNA was also detected in infiltrating lymphocytes and in some morphologically normal epithelial cells in the NPC biopsies (Fig. 2). It was observed that the frequency of such cells was low in the NPC biopsies studied. Only sections from one biopsy (out of 17 ) had consistently distinct EBV DNA staining in the normal epithelial cells. EBV positive cells were randomly found among the cells above the basal layer, with no identifiable areas of concentration of EBV positive cells. None of the six biopsies read non-malignant contained any EBV positive epithelial cells.

A comparative study was carried out on the relative merit of digoxigenin-la-

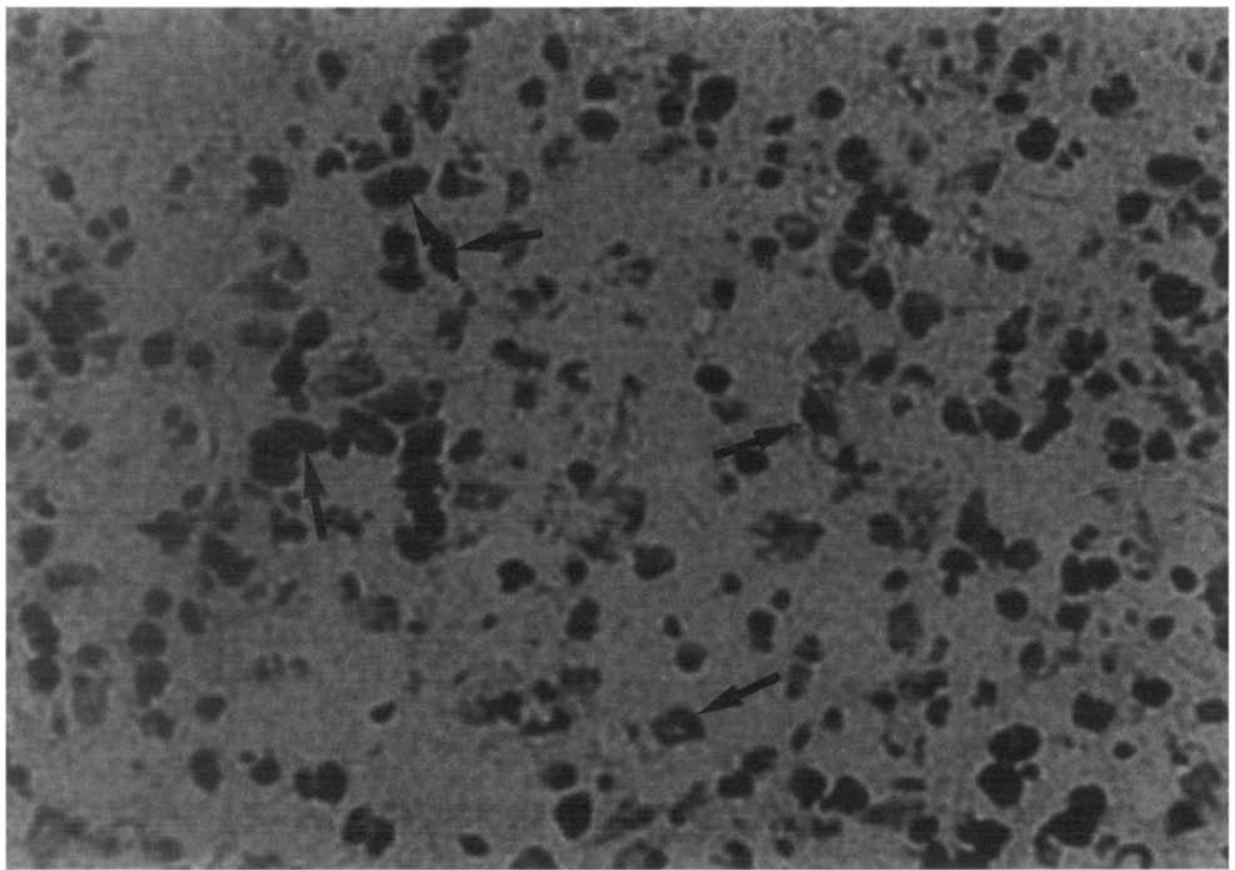

Fig. 1. In situ cytohybridisation using digoxigenin labelled DNA probe on a cross section of a NPC biopsy. ( $\rightarrow$ Tumour cells containing EBV DNA). 


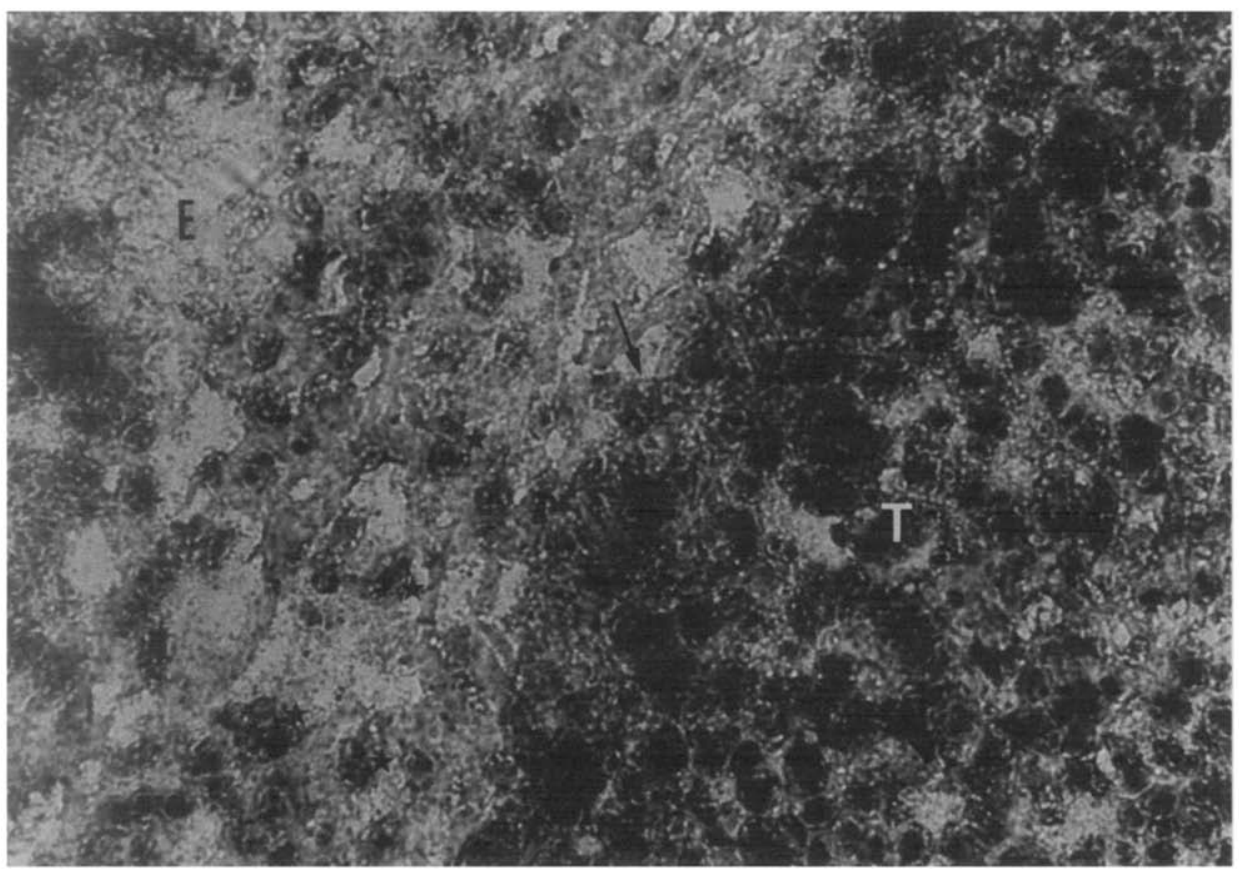

Fig. 2. In situ cytohybridisation demonstrating the presence of EBV DNA in morphologically normal epithelial cells in a cross-section of a NPC biopsy. T, tumour cells containing EBV DNA; $\rightarrow$, interface between epithelial basement membrane and stroma; E, epithelium. Note positive cells on basal layer $\left({ }^{*}\right)$.

belled total EBV DNA probe and ${ }^{3} \mathrm{H}$-labelled BamHI W EBV probe in in situ cytohybridisation of 11 NPC biopsies. Positive hybridisation was detected in every case when digoxigenin EBV probe was used, but only four stained positive with ${ }^{3} \mathrm{H}$ probe. All six non-malignant biopsies tested negative for EBV DNA in the epithelial cells by both digoxigenin and ${ }^{3} \mathrm{H}$ probes.

There were no false positive reactions with either probe, since negative controls (tonsil and BJAB) which were always included in the test consistently tested negative. There was background staining in the ${ }^{3} \mathrm{H}$ technique but this could be identified as such staining was not confined to intracellular spaces. There was no background staining in the digoxigenin technique.

\section{Discussion}

Results of in situ cytohybridisation using digoxigenin-labelled EBV probe demonstrated that it is a sensitive and specific method for the detection of EBV positive cells in NPC biopsies. The method reduced the experimental time of 5 weeks required for in situ cytohybridisation using ${ }^{3} \mathrm{H}$-labelled EBV probe to $96 \mathrm{~h}$. It is a much more sensitive method, detecting EBV DNA positive cells in $100 \%(17 / 17)$ 
compared to $36 \%(4 / 11)$ of NPC biopsies tested. It is specific since negative controls of tonsil and EBV negative lymphoblastoid cells were consistently negative. Being a nonradioactive method, it eliminates the risk of radioactivity. Since all the seventeen NPC biopsies tested were positive for EBV DNA and all the six nonmalignant biopsies were negative for EBV DNA, in situ cytohybridisation by digoxigenin-labelled EBV probe is of diagnostic potential for NPC.

Morphologically epithelial cells positive for EBV DNA were detected in one of the NPC biopsies. No such cells were detected in non-malignant biopsies from the post-nasal space. Whether the observation has any significance with respect to the etiopathogenesis of NPC remains to be elucidated.

\section{Acknowledgement}

This study was supported by University Malaya, R \& D Grant 3/01/05 and a grant by Sander's Foundation.

\section{References}

Dooley, S., Radtke, J., Blin, N. and Unteregger, G. (1988) Rapid detection of DNA-binding factors using protein-blotting and digoxygenin-dUTP marked probes. Nucleic Acids Res. 16, 11839.

Epstein, M.A. and Barr, Y.M. (1964) Cultivation in vitro of human lymphoblasts from Burkitt's malignant lymphoma. Lancet 1, 252-253.

Feinberg, A.P. and Vogelstein, B. (1983) A technique for radiolabeling DNA restriction endonuclease fragments to high specific activity. Anal. Biochem. 132, 6-14.

Henle, W., Henle, G., Ho, H.C., Burton, P., Cachin, Y., Clifford, P., De Schryver, A., de The, G., Diehl, V. and Klein, G. (1970) Antibodies to Epstein-Barr virus in nasopharyngeal carcinoma, other head and neck neoplasms and control groups. J. Natl. Cancer Inst. 44, 225-231.

Klein, G., Giovanella, B.C., Lindahl, T., Fialkow, P.J., Singh, S. and Stehlen, J.S. (1974) Direct evidence for the presence of Epstein-Barr virus DNA and nuclear antigen in malignant epithelial cells from patients with poorly differentiated carcinoma of the nasopharynx. Proc. Natl. Acad. Sci. USA $71,4737-4741$.

Nonoyama, M. and Pagano, J. (1972) Replication of viral DNA and breakdown of cellular DNA in Epstein-Barr virus infection. J. Virol. 2, 714-716.

Nonoyama, Y., Huang, C.H., Pagano, J., Klein, G. and Singh, S. (1973) DNA of Epstein-Barr virus detected in tissues of Burkitt's lymphoma and nasopharyngeal carcinoma. Proc. Natl. Acad. Sci. USA 70, 3265-3268.

Old, L.J., Boyse, E.A., Oettgen, H.E., de Harven, E., Geering, G., Willamson, B. and Clifford, P. (1966) Precipitating antibodies in human serum to an antigen present in cultured Burkitt's lymphoma cells. Proc. Natl. Acad. Sci. USA 56, 1699-1704.

Shanmugaratnam, K. and Sobin, L.H. (1978) Nasopharyngeal carcinoma. In: International Histological Classification of Tumours 19, 13, pp. 13-15, WHO, Geneva.

Skare, J. and Strominger, J.L. (1980) Cloning and mapping of BamHI endonuclease fragments of DNA from the transforming B95-8 strain of Epstein-Barr virus. Proc. Natl. Acad. Sci. USA 77, 3860-3864.

Wolf, H., zur Hausen, H. and Becker, Y. (1973) Epstein-Barr viral genomes in epithelial nasopharyngeal carcinoma cells. Nature New Biol. 244, 245-247.

Yamaguchi, J., Hinuma, Y. and Grace, J.T. (1967) Structure of virus particles extracted from a Burkitt's lymphoma cell line. J. Virol. 1, 640-642.

zur Hausen, H., Hinuma, Y., Schulte-Holthausen, H., Klein, G., Henle, W., Henle, G., Clifford, P. and Santesson, L. (1970) EBV DNA in biopsies of Burkitt's tumours and anaplastic carcinomas of the nasopharynx. Nature (London) 288, 1056-1058. 